\title{
Stigma Negatif Masyarakat terhadap Pasien Korona: Kajian Pragmatik
}

\author{
Mimas Ardhianti \\ Pendidikan Bahasa Indonesia, Universitas PGRI Adi Buana Surabaya \\ mimasardhianti@unipasby.ac.id
}

DOI: https://doi.org/10.32528/bb.v6i1.4196

First received: 25-01-2021

Final proof received: $28-02-2021$

\begin{abstract}
ABSTRAK
Situasi pandemi covid-19 telah memunculkan berbagai stigma negatif di kalangan masyarakat Indonesia sehingga memunculkan diskriminasi terhadap korban. Stigma merupakan pemberian nama terhadap korban yang dirasa memiliki kekurangan dan tidak sama dengan masyarakat pada umumnya. Penelitian ini bertujuan menjelaskan dan mendeskripsikan stigma negatif masyarakat terhadap pasien positif korona dengan menggunakan kajian pragmtik. Pendekatan penelitian ini adalah pendekatan kualitatif. Objek penelitian ini berasal dari kumpulan beritaberita yang berisi stigma negatif masyarakat terhadap pasien positif korona. Data penelitian ini berupa kata, frasa, kalimat yang berisi stigma negatif masyarakat terhadap pasien positif korona. Teknik pengumpulan data penelitian ini adalah mengumpulkan, memilah, menyeleksi data, menjelaskan dan mendeskripsikan data berupa pernyataan- pernyataan masyarakat terhadap pasien positif korona. Teknik analisis data adalah mengabsahkan temuan penelitian dan verifiksi serta penarikan simpulan. Hasil analisis membuktikan stigma negatif terhadap pasien korona dibuktikan melalui adanya data lingual yang mengandung unsur penghinaan, pencemaran nama baik berupa label.
\end{abstract}

Kata Kunci: stigma negatif; pasien positif korona; pragmatik

\begin{abstract}
The Covid-19 pandemic situation has generated various negative stigmas among the Indonesian people, resulting in discrimination against victims. Stigma is the giving of names to victims who feel they have shortcomings and are not the same as a society in general. This study aims to explain and describe the negative stigma of society towards positive corona patients using a practical study. This research approach is qualitative. The object of this research comes from a collection of news that contains the negative stigma of society towards positive corona patients. The data of this research are in the form of words, phrases, sentences that contain the negative stigma of society towards positive corona patients. The data collection technique of this research is collecting, sorting, selecting data, explain and describe data in the form of public statements about corona positive patients. The data analysis technique is to validate the research
\end{abstract}


findings and verification and draw conclusions. The results of the analysis prove that the negative stigma against corona patients is proven by the presence of lingual data that contains elements of insulting, defamation in the form of labels.

\section{Keywords: negative stigma; corona positive patient; pragmatics}

\section{PENDAHULUAN}

Stigma negatif terhadap pasien Covid di Indonesia sudah merajela. Banyak berita yang mengangkat bagaimana sikap masyarakat yang menghindari serta mencemooh korban. Penulis sendiri melihat tetangga yang diberi label sebagai corona dan menjadi pembicaraan di lingkungan tempat tinggal. Bukan hanya pasien yang menerima label corona tersebut, keluarga pasien tidak lepas dengan diskriminasi yang dilakukan masyarakat, seperti kasus anak yang dikucilkan oleh teman-temannya dikarenakan orang tuanya menjadi pasien. Padahal anak tersebut hasil tes swabnya menunjukan negatif. Hal ini yang menjadi latar belakang adanya penelitian terhadap stigma negatif terhadap pasien korona.

Menurut Rianto (2017) stigma dapat mendorong seseorang untuk memunyai prasangka pemikiran, perilaku, dan atau tindakan oleh pihak pemerintah, masyarakat, pemberi kerja, penyedian layanan kesehatan, teman sekerja, para teman dan keluarga. Hal tersebut dapat menyebabkan penurunan percaya diri, kehilangan motivasi, penarikan diri dari kehidupan sosial, menghindari pekerjaan, interaksi dalam kesehatan dan kehilangan perencanaan masa depan (Kleinman, 2002, hal.37). Stigma merupakan fenomena yang terjadi ketika seseorang diberikan labeling, stereotip, separation, dan mengalami diskriminasi (Chaer, 2010, hal 72).

Kajian stigma merupakan sebuah fakta bahwa kebanyakan orang memiliki pengetahuan tentang seperangkat stereotip tidak menyiratkan bahwa mereka setuju dengan mereka (Jussim, 1995). Berbeda dengan stereotip, yaitu keyakinan, sikap prasangka melibatkan komponen evaluatif (umumnya negatif) (Eagly, 1993). Prasangka juga menghasilkan respons emosional, misalnya kemarahan atau ketakutan kepada kelompok yang terstigmatisasi. Prasangka, yang pada dasarnya merupakan respon kognitif dan afektif, mengarah pada diskriminasi, reaksi perilaku (Crocker, 1998). Prasangka yang menimbulkan kemarahan dapat mengarah pada perilaku bermusuhan misalnya, melukai kelompok minoritas secara fisik (Weiner, 1995).

Dalam hal penyakit korona, menimbulkan ketakutan mengarah pada penghindaran melakukan kontak secara fisik atau prasangka yang mengarah ke dalam mengarah pada diskriminasi diri. Penelitian menunjukkan stigma diri dan ketakutan akan penolakan oleh orang lain menyebabkan banyak orang tidak mengejar kesempatan hidup untuk diri mereka sendiri (Link, 1997). Hal ini sejalan dengan Abudi (2020) bahwa stigma negatif pada penderita korona maupun keluarganya timbul akibat pandemik dunia pada awal tahun 2020. Pandemi korona merupakan penyakit menular dengan proses penularannya sangat cepat dan dapat 
berakibat pada kematian. Untuk saat ini virus COVID-19 belum ada obatnya (Susilo, 2019).

Stigma negatif terhadap pasien korona di masyarakat diperparah dengan pemberitaaan yang menyesatkan di media sosial. Pemberitaan tentang korona menjadi informasi yang menjadi trending setiap hari terhitung sejak adanya kasus pandemi tersbut. Permasalahan ini bukan saja terjadi di masyarakat tetapi juga menimpa tenaga medis yang menangani pasien yang mendapatkan perlakuan yang sama dari masyarakat. Sent (2014) bahwa interaksi sosial harus dipahami sebagai lembaga sosial yang berkaitan dengan bahasa di masyarakat. Oleh karena itu, berdasarkan latar belakang di atas, penelitian ini bertujuan untuk menganalisis beberapa kasus yang berkaitan dengan stigma negatif. Keterjalinan antara kajian stigma dengan bahasa terdapat pada aspek sosiologi dan pragmatik.

\section{METODE PENELITIAN}

Pendekatan pada penelitian ini adalah pendekatan kualitatif. Dalam penelitian kualitatif, data yang muncul berupa kata, frasa, kalimat berupa tuturan negatif masyarakat terhadap pasien positif korona. Creswell (2010, hal.15) memandang penelitian kualitatif sebagai proses penelisikan dan eksplorasi permasalahan sosial. Pendekatan kualitatif dipilih karena memiliki karakteristik yang sama dengan penelitian ini. Keselarasan penelitian ini dengan pendekatan penelitian kualitatif karena memiliki karakteristik yakni penelitian kualitatif menggunakan data yang bersifat deskriptif. Pendekatan deskriptif bertujuan membuat deskripsi suatu objek kajian secara sistematis, faktual, dan akurat mengenai data sehingga didapatkan pembahasan data secara alamiah.

Subjek penelitin ini adalah masyarakat sekitar di Kecamatan Tandes, Kecamatan Rungkut, dan Kecamatan Taman yang terkena dampak virus korona. Objek data yang diambil terdiri atas mahasiswa, swasta, pedagang, dan guru. Data pada penelitian ini berupa kata, frasa, kalimat tuturan negatif masyarakat masyarakat terhadap pasien positif korona. Untuk mengumpulkan data, peneliti menggunakan prosedur wawancara, rekaman, dan dokumentasi. Prosedur tersebut perlu dilakukan agar dari pengumpulan data yang dilakukan dapat memperoleh data yang tepat, yang mampu memberi jawaban atas dua rumusan masalah yang ada dalam penelitian ini.

\section{PEMBAHASAN}

\section{1) Bentuk Tindak Tutur Ilokusi}

a) Tindak Tutur Representatif

Tindak tutur ilokusi representatif merupakan tindak tutur yang mengikat penutur kepada kebenaran atas hal yang diujarkan dan mengandung maksud tertentu yang memiliki pengaruh kepada petutur. Beberapa data tentang tindak tutur ilokusi representatif sebagai berikut.

(1) Menurut saya virusnya sendiri sendiri ya itu tidak terlalu membahayakan untuk mereka yang tidak memiliki riwayat penyakit tertentu $(\mathbf{S N / 2 0 2 0})$ 
Kutipan (1) percakapan di atas merupakan bentuk tindak tutur ilokusi. Dikatakan demikian, karena pada percakapan tersebut mendeskripsikan bahwa penutur mengatakan hal kebenaran mengenai bahaya virus korona bagi seseorang yang memiliki riwayat penyakit tertentu.

(2) Saya nggak punya nggak punya riwayat penyakit apapun nggak punya penyakit bawaan apapun jadi bagi saya tidak akan menjadi terlalu berbahaya (SN/2020)

Kutipan (2) percakapan di atas merupakan bentuk tindak tutur ilokusi. Dikatakan demikian, karena pada percakapan tersebut mendeskripsikan bahwa penutur mengatakan hal kebenaran mengenai dirinya yang tidak memiliki riwayat penyakit apapun sehingga tidak terlalu berbahaya virus covid itu sendiri.

b) Tindak Tutur Direktif

Tindak tutur ilokusi direktif merupakan tindak tutur yang dilakukan penutur atas hal diujarkan dengan mengandung maksud tertentu yang memiiki pengaruh kepada petutur untuk melakukan tindakan yang disebutkan di dalam tuturan itu. Beberapa data tentang tindak tutur ilokusi direktif sebagai berikut.

(3) Kalau saya baca dari beberapa jurnal itu ilmuwan luar negeri sendiri itu sudah bilang bahwa pemutasian nya ini itu itu di apa namanya dari alam dari alam sendiri jadi memang dia berkembang sendiri bukan karena buatan (PN/2020)

Kutipan (3) percakapan di atas merupakan bentuk tindak tutur direktif. Dikatakan demikian, karena pada percakapan tersebut mendeskripsikan bahwa penutur bermaksud kita sebagai masyarakat perlu mengetahui informasi sebanyak-banyaknya mengenai virus covid tersebut.

(4) Kita awalnya belum kenal kok cuman bisa ngatasin flu lama-lama udah kenal kok cuman kita juga akan berkembang kan jadi lebih kuat juga (JA/2020)

Kutipan (4) percakapan di atas merupakan bentuk tindak tutur direktif. Dikatakan demikian, karena pada percakapan tersebut mendeskripsikan bahwa penutur bermaksud dengan pengobatan untuk gejala influenza bisa diatasi namun untuk gejala virus covid tidak bisa dengan pengobatan yang sama.

c) Tindak Tutur Ekspresif

Tindak tutur ilokusi ekspresif merupakan tindak tutur ilokusi yang mengungkapkan atau mengutarakan atas hal yang diujarkannya dengan mengandung maksud tersirat yang disebutkan di dalam tuturan itu. Beberapa data tentang tindak tutur ilokusi ekspresif sebagai berikut.

(5) Sebenarnya ini flu termasuk coronavirus cuman sudah permutasi permutasi kan dia berkembang berkembanglah berkembangnya ini kan kalau apa bos teori-teori konspirasi $(\mathbf{A R / 2 0 2 0 )}$ 
Kutipan (5) percakapan di atas merupakan bentuk tindak tutur ekspresif. Dikatakan demikian, karena pada percakapan tersebut mendeskripsikan bahwa penutur bermaksud virus korona tersebut telah bermutasi lama dan berkembang secara cepat menurut teori konspirasi yang ada di sosial media.

(6) Ketika mengetahui banyaknya informasi yang seperti itu justru saya merasa nggak apa ya nggak Bukannya nggak terlalu ketakutan malahan nggak terlalu ketakutan (PG/2020)

Kutipan (6) percakapan di atas merupakan bentuk tindak tutur ekspresif. Dikatakan demikian, karena pada percakapan tersebut mendeskripsikan bahwa penutur bermaksud mengetahui adanya virus covid ini tidak menjadikan dirinya ketakutan maupun khawatir akan akibatnya karena ia menganggap virus tersebut seperti pada umumnya sejenis influenza.

d) Tindak Tutur Komisif

Tindak tutur ilokusi komisif merupakan tindak tutur ilokusi yang mengikat penuturnya di masa yang akan datang untuk melaksanakan atas hal disebutkan di dalam tuturannya. Beberapa data tentang tindak tutur ilokusi komisif sebagai berikut.

(7) Saya mikirnya udah berarti solusinya adalah saya harus memperkuat imun tubuh sehat membatasi akhirnya kayak ada kesehatan itu saya mau menganggap itu pencegahan-pencegahan (AR/2020).

Kutipan (7) percakapan di atas merupakan bentuk tindak tutur komisif. Dikatakan demikian, karena pada percakapan tersebut mendeskripsikan bahwa penutur akan selalu menjaga kekebalan tubuh dengan berbagai suplemen dengan begitu ia telah melaksanakan pencegahan penularan covid 19.

(8) Harus pakai masker setelah saya baca Oh iya sih soalnya akan ada yang namanya OTG orang kayaknya itu sehat tapi kan yang namanya terus kan kita nggak tahu kalau kita di dalam tubuh kita itu apa aja (AK/2020)

Kutipan (8) percakapan di atas merupakan bentuk tindak tutur komisif. Dikatakan demikian, karena pada percakapan tersebut mendeskripsikan bahwa penutur akan menggunakan masker karena terdapat orang yang terlihat sehat namun ternyata berstatus sebagai OTG dengan begitu ia telah melaksanakan pencegahan penularan covid 19.

e) Tindak Tutur Deklarasi

Tindak tutur ilokusi deklarasi merupakan tindak tutur yang berusaha mengungkapkan suatu pelaksanaan yang mengakibatkan adanya suatu hal (situasi, keadaan, dan sebagainya) yang baru dengan realitis. Beberapa data stigma negatif dalam wujud tindak tutur ilokusi deklarasi sebagai berikut.

(9) Lebih banyak populasi orang lanjut usia nya yang banyak yang meninggal itu yang manis gitu Oh berarti itu berbahaya bagi mereka yang memiliki 
sistem imun rendah ditambah kemudian ada riwayat penyakit sendiri sendiri (PN/2020)

Kutipan (9) percakapan di atas merupakan bentuk tindak tutur deklarasi. Dikatakan demikian, karena pada percakapan tersebut mendeskripsikan bahwa penutur bermaksud adanya virus covid ini sangat beresiko tinggi bagi seseorang yang memiliki riwayat penyakit dan daya tahan tubunhya lemah

(10) Kalau saya bilang bukan masyarakatnya yang lebih baik karena itu tadi ya mungkin mereka kan nggak semua orang itu menerima informasi dengan pikiran yang positif (JN/2020).

Kutipan (10) percakapan di atas merupakan bentuk tindak tutur deklarasi. Dikatakan demikian, karena pada percakapan tersebut mendeskripsikan bahwa penutur bermaksud mayoritas warga indonesia sebagian tidak bisa menerima informasi dengan pikiran positif, mereka telah merasa ketakutan yang berlebihan terhadap virus covid ini sehingga tidak mencari informasi yang lebih lanjut lagi.

Dengan demikian, hasil penelitian ini memperkuat pernyataan Nurkhaliza (2019) menyatakan bahwa dalam bentuk tindak tutur ilokusi ditemukan lima jenis tindak ilokusi, yaitu (a) asertif, (b) direktif, (c) ekspresif, (d) komisif, dan (e) deklaratif. Hal tersebut diperkuat oleh Apriastuti (2017) yang menyatakan bahwa bentuk tindak tutur bermodus deklaratif, bentuk tindak tutur bermodus interogatif, dan bentuk tindak tutur bermodus imperatif.

\section{2) Fungsi Tindak Tutur Ilokusi}

Fungsi tindak tutur berhubungan erat dengan jenis tutur. Tindak tutur yang disebutkan terdiri atas fungsi dari jenis representatif, fungsi dari jenis direktif, fungsi dari jenis ekspresif, fungsi dari jenis komisif, dan fungsi dari jenis deklarasi. Berikut dapat dijelaskan berbagai macam fungsi tindak tutur ditemukan dalam Stigma Negatif terhadap Pasien Positif Korona. Saraswaty (2018) menjelaskan bahwa stigma negatif merupakan sesuatu yang dianggap bernilai negatif terhadap suatu keadaan atau kondisi seseorang untuk mengetahui karakteristik atau penilain terhadap orang lain.

\section{a. Fungsi dari Jenis Representatif}

Jenis representatif memiliki berbagai fungsi percakapan yang ditemukan dalam penelitian ini, antara lain: menyarankan, menyatakan, mengemukakan pendapat, menyebutkan, mengakui, mengklaim, dan melaporkan. Untuk lebih jelas berikut data telah dijelaskan.

\section{1) Jenis Representatif yang Berfungsi Mengungkapkan pendapat}

(11) Menurut saya virusnya sendiri sendiri ya itu tidak terlalu membahayakan untuk mereka yang tidak memiliki riwayat penyakit tertentu (SN/2020).

(12) Kalau saya kemudian punya sakit TB atau Asma mungkin akan memperparah penyakit saya yang bikin jadi berbahaya itu penyebarannya (AK/2020). 
Kutipan (11) di atas merupakan fungsi mengungkapkan pendapat. Data tersebut berfungsi mengungkapkan pendapat terhadap virus korona. Dikatakan demikian, karena pada percakapan tersebut penutur mengungkapkan pendapatnya bahwa virus korona tidak terlalu membahayakan karena ia tidak memiliki riwayat penyakit tertentu.

Kutipan (12) di atas merupakan fungsi mengungkapkan pendapat. Data tersebut berfungsi mengungkapkan pendapat terhadap virus korona. Dikatakan demikian, karena pada percakapan tersebut penutur mengungkapkan pendapatnya jika ia memiliki riwayat penyakit seperti diabetes dan asma maka memiliki resiko sangat besar atas penyebaran virus korona tersebut.

\section{2) Bentuk tindak tutur representatif mengklaim}

(13) Saya nggak Punya nggak Punya riwayat penyakit apapun nggak punya penyakit bawaan apapun jadi bagi saya tidak akan menjadi terlalu berbahaya $(\mathbf{A R / 2 0 2 0})$.

(14) Penyebarannya yang cepat jadi penularannya itu cepat sehingga mungkin saya nggak berbahaya tapi bisa jadi berbahaya untuk orang tua saya yang punya penyakit bawaan (SN/2020).

Kutipan (13) di atas merupakan fungsi mengklaim. Data tersebut berfungsi mengklaim Dikatakan demikian, karena pada percakapan tersebut penutur bertanggung jawab bahwa tuturan yang diucapkan itu memang fakta dan dapat dibuktikan di realita dan masyarakat di sekitar bahwa yang beresiko tinggi terjangkit penularan covid adalah orang yang memiliki riwayat penyakit tertentu.

Kutipan (14) di atas merupakan fungsi mengklaim. Data tersebut berfungsi mengklaim Dikatakan demikian, karena pada percakapan tersebut penutur bertanggung jawab atas tuturan yang diucapkan itu memang fakta dan dapat dibuktikan di realita bahwa yang beresiko tinggi adalah bagi orang yang memiliki riwayat penyakit tertentu. Hal ini sejalan dengan pernyataan Indrayanti (2019) bahwa tindak tutur ilokusi representatif, direktif, komisif, ekspresif, dan isbati. Tindak tutur ilokusi representatif meliputi representatif memberitahukan, mengeluh, membanggakan, mengakui, dan menuntut. Tindak tutur ilokusi direktif meliputi direktif mengajak, memerintah, menasihati, dan meminta. Tindak tutur ilokusi.

\section{b. Fungsi dari Jenis Direktif}

Jenis direktif memiliki berbagai fungsi percakapan yang ditemukan dalam penelitian ini, antara lain: memesan, nasihat, memohon, menyuruh, mendesak, menagih, dan perintah. Untuk lebih jelas berikut data telah dijelaskan. Fungsi direktif nasihat

(15) Kalau saya baca dari beberapa jurnal itu ilmuwan luar negeri sendiri itu sudah bilang bahwa pemutasian nya ini itu itu di apa namanya dari alam dari alam sendiri jadi memang dia berkembang sendiri bukan karena buatan $(\mathrm{AR} / \mathbf{2 0 2 0})$ 
(16) Kita awalnya belum kenal kok cuman bisa ngatasin flu lama-lama udah kenal kok cuman kita juga akan berkembang kan jadi lebih kuat juga $(\mathrm{AK} / \mathbf{2 0 2 0})$

Kutipan (15) di atas merupakan fungsi nasihat. Data tersebut berfungsi sebagai nasihat kepada lawan tutur. Dikatakan demikian, karena pada percakapan tersebut tuturan itu dimaksudkan penuturnya agar melakukan tindakan yang sesuai dengan disebutkan dalam tuturannya bahwa virus korona memang bermutasi secara alami bukan buatan seperti yang dikatakan teori konspirasi.

Kutipan (16) di atas merupakan fungsi nasihat. Data tersebut berfungsi sebagai nasihat kepada lawan tutur. Dikatakan demikian, karena pada percakapan tersebut tuturan itu dimaksudkan penuturnya agar melakukan tindakan yang sesuai dengan disebutkan dalam tuturannya bahwa semua jenis influenza yang bermutasi baru apabila kita terjangkit maka secara tidak langsung kita akan kebal dengan virus korona tersebut.

Dengan demikian, hasil penelitian di atas memperkuat pernyataan Yuliarti (2015) bahwa fungsi pragmatis tindak tutur direktif ditemukan fungsi direktif yang meliputi fungsi mengajak, perintah, memperingatkan, bertanya, melarang, menasihati, mendorong, memohon, mengizinkan, menyarankan, mengajak, meminta, dan mengkomando.

\section{c. Fungsi dari jenis ekspresif}

Jenis ekspresif memiliki berbagai fungsi percakapan yang ditemukan v, antara lain: ucapan selamat, ucapan terima kasih, mengkritik, mengeluh, menyalahkan, memuji, meminta maaf, menyindir. Untuk lebih jelas berikut data telah dijelaskan. Fungsi ekspresif mengkritik

(17) Sebenarnya ini flu termasuk coronavirus cuman sudah permutasi permutasi kan dia berkembang berkembanglah berkembangnya ini kan kalau apa bos teori-teori konspirasi (JN/2020)

(18) Ketika mengetahui banyaknya informasi yang seperti itu justru saya merasa nggak apa ya nggak Bukannya nggak terlalu ketakutan malahan nggak terlalu ketakutan (PN/2020).

Kutipan (17) di atas merupakan tindak tutur ekpresif. Data tersebut berfungsi sebagai mengeluh kepada lawan tutur. Dikatakan demikian, karena pada percakapan tuturan itu dimaksudkan sebagai evaluasi tentang hal yang dituturkannya bahwa virus korona telah bermutasi dan berkembang lebih cepat.

Kutipan (18) di atas merupakan tindak tutur ekpresif. Data tersebut berfungsi sebagai mengeluh kepada lawan tutur. Dikatakan demikian, karena pada percakapan tuturan itu dimaksudkan sebagai evaluasi tentang hal yang dituturkannya bahwa dirinya tidak begitu khawatir seberapa bahayakah virus korona baginya. 


\section{d. Fungsi dari jenis komisif}

Jenis komisif memiliki berbagai fungsi percakapan yang ditemukan v, antara lain: bersumpah, berjanji, menawarkan sesuatu, dan menyatakan kesanggupan. Erlian (2013) menyatakan bahwa Tindak tutur komisif adalah tindak tutur yang mengikat penuturnya untuk melaksanakan apa yang disebutkan dalam tuturannya. Untuk lebih jelas berikut data telah dijelaskan. Fungsi komisif menyatakan kesanggupan

(19) Saya mikirnya udah berarti solusinya adalah saya harus memperkuat imun tubuh sehat membatasi akhirnya kayak ada kesehatan itu saya mau menganggap itu pencegahan-pencegahan (AR/2020)

(20) Harus pakai masker setelah saya baca Oh iya sih soalnya akan ada yang namanya OTG orang kayaknya itu sehat tapi kan yang namanya terus kan kita nggak tahu kalau kita di dalam tubuh kita itu apa aja (ZH/2020)

Kutipan (19) di atas merupakan tindak tutur komisif. Data tersebut berfungsi sebagai menyatakan kesanggupan kepada lawan tutur. Dikatakan demikian, karena pada percakapan tuturan itu mengikat penuturnya untuk melaksanakan hal yang dituturkannya sebagai konsekuensi bagi dirinya untuk memenuhi yang telah diucapkannya. yaitu penutur berusaha membuktikan kepada mitra tutur bahwa mereka sanggup untuk mempertahankan daya tahan tubuh tetap sehat

Kutipan (20) di atas merupakan tindak tutur komisif. Data tersebut berfungsi sebagai menyatakan kesanggupan kepada lawan tutur. Dikatakan demikian, karena pada percakapan tuturan itu mengikat penuturnya untuk melaksanakan hal yang dituturkannya sebagai konsekuensi bagi dirinya untuk memenuhi yang telah diucapkannya. yaitu penutur berusaha membuktikan kepada mitra tutur bahwa mereka sanggup untuk menggunakan masker ketika keluar rumah.

\section{e. Fungsi dari jenis deklarasi}

Jenis direktif memiliki berbagai fungsi percakapan yang ditemukan dalam penelitian ini, antara lain: mengesankan, memutuskan, melarang, berpasrah, dan mengucilkan. Untuk lebih jelas berikut data telah dijelaskan.

\section{1) Fungsi deklarasi memutuskan}

(21) Lebih banyak populasi orang lanjut usia nya yang banyak yang meninggal itu yang manis gitu Oh berarti itu berbahaya bagi mereka yang memiliki sistem imun rendah ditambah kemudian ada riwayat penyakit sendiri sendiri (ZH/2020)

(22) Kalau saya bilang bukan masyarakatnya yang lebih baik karena itu tadi ya mungkin mereka kan nggak semua orang itu menerima informasi dengan pikiran yang positif (AR/2020)

Kutipan (21) di atas merupakan fungsi deklarasi. Data tersebut berfungsi sebagai memutuskan kepada lawan tutur. Dikatakan demikian, karena pada 
percakapan tersebut tuturan itu dimaksudkan penutur untuk memberikan sesuatu keputusan atau untuk memutuskan suatu hal atau suatu perkara. Yaitu penutur memutuskan bahwa seseorang yang memiliki riwayat penyakit dan daya tahn tubuh yag lemah mudah untuk terserang virus korona

Kutipan (22) di atas merupakan fungsi deklarasi. Data tersebut berfungsi sebagai memutuskan kepada lawan tutur. Dikatakan demikian, karena pada percakapan tersebut tuturan itu dimaksudkan penutur untuk memberikan sesuatu keputusan atau untuk memutuskan suatu hal atau suatu perkara. Yaitu penutur memutuskan bahwa masyarakat sebaiknya mencari informasi yang lebih akurat dan sebanyak-banyaknya agar tidak menjadikan kekhawatiran yang berlebih.

\section{2) Fungsi deklarasi melarang}

(23) Kita nggak perlulah makanan kita bukan lagi dalam masa berlaku dalam masa pernah kan kalau kita sampai borong suplemen sampai burung segala macem itu bukan bukan hal yang membuat mereka yang ketakutan (AK/2020).

Kutipan (23) di atas merupakan fungsi deklarasi. data tersebut berfungsi sebagai melarang kepada lawan tutur. Dikatakan demikian, karena pada percakapan tersebut tuturan itu dimaksudkan penutur untuk melarang sesuatu yang harus ditaati oleh seseorang terhadap keadaan yang tidak membolehkan. Yaitu penutur melarang masyarakat ketakutan akan virus korona dan membeli kebutuhan pokok, suplemen vitamin, hand sanitizier secara berlebihan karena akan mengakibatkan harga akan melambung tinggi dan barang-barang yang dibutuhkan akan menjadi langka.

Tindak tutur deklarasi dilakukan penutur dengan maksud atau tujuan untuk menciptakan status, keadaan yang baru seperti memutuskan, membatalkan, melarang, dan mengizinkan (Gunarwan, 1994: 48). Hal ini diperkuat oleh Yule (2006:92) menyatakan bahwa tindak tutur deklarasi adalah jenis tindak tutur yang mengubah dunia melalui tuturan. Tindak tutur deklarasi digolongkan ke dalam subkajian tindak tutur ilokusi. Berdasarkan analisis data di atas, ditemukan jenis tindak tutur ilokusi yang pertama yakni representatif. Pada penelitian ini tujuh tuturan yang diambil dalam percakapan wawancara penelitian tujuh tuturan tersebut dikatakan tindak tutur representatif Searle (dalam Rahardi, 2005, hal.29) jenis dari tuturan representatif dapat ditandai dengan tuturan si penutur yang mengikat kepada kebenaran suatu hal yang dapat dibuktikan dalam kehidupan atas yang dikatakannya dengan mudah mempengaruhi mitra tutur.

Hal ini sesuai dengan jenis yang berfungsi sebagai tindak tutur representatif yang terdapat pada Stigma Negatif terhadap Pasien Positif Korona antara lain, menyarankan, menyatakan, menyebutkan, mengklaim, mengakui, melaporkan, dan mengungkapkan pendapat. Tuturan dalam penelitian tersebut tidak dapat dijelaskan secara gamblang tanpa mengetahui konteks pada percakapan tersebut sehingga tindak tutur representatif bersifat eksplisit. Jenis representatif terdapat tujuh tuturan sedangkan fungsi dalam Stigma Negatif terhadap Pasien Positif Korona tindak tutur ilokusi yang berfungsi sebagai mengungkapkan pendapat dapat dikatakan cukup banyak karena ada empat tuturan yang 
mengungkapkan kepada mitra tutur agar dapat mempengaruhinya untuk bertindak terjadi tuturan tersebut.

Dikatakan demikian, karena pada percakapan tersebut penutur mengungkapkan pendapatnya bahwa virus korona tidak terlalu membahayakan karena ia tidak memiliki riwayat penyakit tertentu.Tuturan representatif tersebut dikatakan karena percakapan dalam Stigma Negatif terhadap Pasien Positif Korona juga merupakan cerminan dari kehidupan nyata yang tidak terlepas dari tindak tutur. Tuturan representatif memiliki tujuan yaitu memberikan informasi. Tindak tutur ini berkaitan dengan pengetahuan dan data yang dapat dibuktikan. Namun, tindak tutur representatif terkadang bisa benar ataupun salah. Jenis tindak tutur ilokusi berikutnya yakni direktif. Dalam penelitian tersebut terdapat dua tuturan yang diambil dalam percakapan stigma negatif terhadap pasien positif korona tersebut merupakan tindak tutur ilokusi jenis dan fungsi direktif. Menurut Searle (dalam chaer, 2010:9) jenis dari tuturan direktif dapat ditandai dengan tuturan si penutur dimaksudkan penuturnya agar melakukan tindakan yang sesuai dengan disebutkan dalam tuturannya atau tuturannya berusaha menunjukkan sesuatu yang dapat memberikan pengaruh bagi mitra tutur untuk melakukannya.

Hal ini sesuai dengan jenis yang berfungsi sebagai tindak tutur direktif yang terdapat pada percakapan stigma negatif terhadap pasien positif korona antara lain, memesan, nasihat, perintah, memohon, mendesak, menagih. Tuturan dalam penelitian tersebut tidak dapat dijelaskan secara gamblang tanpa mengetahui konteks pada percakapan tersebut sehingga tindak tutur direktif bersifat eksplisit. Jenis tindak tutur direktif terdapat dua sedangkan dalam Stigma Negatif terhadap Pasien Positif Korona tindak tutur ilokusi yang berfungsi sebagai nasihat ada dua tuturan yang memberikan nasihat kepada mitra tutur untuk melaksanakannya setelah yang diujarkan penutur terjadi pada percakapan Stigma Negatif terhadap Pasien Positif Korona. Tuturan tersebut dapat dijelaskan sebagai berikut.

Dikatakan demikian, karena pada percakapan tersebut dimaksudkan agar penutur melakukan tindakan yang sesuai dengan disebutkan dalam tuturannya bahwa virus korona memang bermutasi secara alami bukan buatan seperti yang dikatakan teori konspirasi. Tuturan direktif berkaitan dengan fakta dengan tujuannya yaitu memberikan informasi. Tindak tutur ini berkaitan dengan pengetahuan dan data yang dapat dibuktikan. Direktif tersebut dikatakan karena cerita dalam Stigma Negatif terhadap Pasien Positif Korona juga merupakan cerminan dari kehidupan nyata yang tidak terlepas dari tindak tutur. Tuturan direktif dapat disimpulkan bahwa adanya suatu tindakan yang dilakukan oleh mitra tutur setelah mendengar tuturan tersebut. Jenis tindak tutur ilokusi yang ketiga yakni ekspresif. Pada penelitian ini ditemukan empat tuturan yang diambil dalam percakapan Stigma Negatif terhadap Pasien Positif Korona empat tuturan tersebut merupakan tindak tutur ilokusi jenis dan fungsi ekspresif. Searle (1971, hal.78) terdapat empat tuturan tersebut dikatakan tindak tutur ekspresif) jenis dari tuturan ekspresif dikatakan karena tuturannya bermaksud untuk mengungkapkan atau menunjukkan sikapnya terhadap keadaan penutur yang tersirat dalam tuturan tersebut. 
Hal ini sesuai dengan jenis yang berfungsi sebagai tindak tutur ekspresif yang terdapat pada percakapan Stigma Negatif terhadap Pasien Positif Korona antara lain, menyindir, memuji, meminta maaf, mengeluh, menyalahkan, ucapan selamat, mengkritik, dan ucapan terima kasih. Tuturan dalam penelitian tersebut tidak dapat dijelaskan secara gamblang tanpa mengetahui konteks pada percakapan tersebut sehingga tindak tutur ekspresif bersifat eksplisit. Jenis ekspresif terdapat empat tuturan sedangkan fungsi dalam Stigma Negatif terhadap Pasien Positif Korona tindak tutur ilokusi yang berfungsi sebagai mengkritik dapat dikatakan fungsi tersebut terdapat empat tuturan yang mengkritik kepada mitra tutur evaluasi tentang hal yang diujarkannya terjadi pada tuturan tersebut dapat dijelaskan sebagai berikut.

Dikatakan demikian, karena pada percakapan tuturan itu dimaksudkan sebagai evaluasi tentang hal yang dituturkannya bahwa tidak setuju dengan pihak pemerintah yang menyarankan untuk berolahraga pada pukul 10 siang sedangkan pada pukul 10 itu bukan waktu yang sesuai untuk berjemur. Tuturan ekspresif tersebut dikatakan karena cerita dalam Stigma Negatif terhadap Pasien Positif Korona juga merupakan cerminan dari kehidupan nyata . Jenis tindak tutur ilokusi yang keempat yakni komisif. Penelitian ini ditemukan enam tuturan yang diambil dalam percakapan Stigma Negatif terhadap Pasien Positif Korona. Enam tuturan tersebut merupakan tindak tutur ilokusi jenis dan fungsi komisif enam tuturan tersebut dikatakan tindak tutur komisif Searle (dalam Chaer, 2010: 29) jenis dari tuturan komisif dikatakan karena tuturannya bermaksud untuk menunjukkan atau mengungkapkan kepada hal yang masih terikat pada suatu tindakan yang akan datang.

Hal ini sesuai dengan jenis yang berfungsi sebagai tindak tutur komisif yang terdapat pada percakapan Stigma Negatif terhadap Pasien Positif Korona antara lain, bersumpah, berjanji, menawarkan sesuatu, dan menyatakan kesanggupan. Tuturan dalam penelitian tersebut tidak dapat dijelaskan secara gamblang tanpa mengetahui konteks pada percakapan tersebut sehingga tindak tutur komisif bersifat eksplisit. Jenis komisif terdapat enam tuturan sedangkan fungsi dalam Stigma Negatif terhadap Pasien Positif Korona tindak tutur ilokusi yang berfungsi sebagai menyatakan kesanggupan yang dapat dikatakan cukup banyak karena fungsi tersebut terdapat enam tuturan yang menyatakan kesanggupan kepada mitra tutur untuk melaksanakan hal yang dituturkan ini terjadi pada percakapan Stigma Negatif terhadap Pasien Positif Korona tuturan tersebut dapat dijelaskan sebagai berikut.

Dikatakan demikian, karena pada percakapan tuturan itu dalam tuturannya sebagai konsekuensi bagi dirinya untuk memenuhi yang telah diucapkannya. yaitu penutur berusaha membuktikan kepada mitra tutur bahwa mereka sanggup untuk mempertahankan daya tahan tubuh tetap sehat. Tuturan komisif tersebut dikatakan karena cerita dalam percakapan Stigma Negatif terhadap Pasien Positif Korona juga merupakan cerminan dari kehidupan nyata yang tidak terlepas dari tindak tutur. Tuturan komisif berkaitan dengan konsekuensi bagi penutur dapat memenuhi atas ujarannya serta pengetahuan dan data yang dapat dibuktikan. 
Jenis tindak tutur ilokusi yang kelima yakni deklarasi ditemukan sebanyak enam tuturan yang diambil dalam percakapan Stigma Negatif terhadap Pasien Positif Korona tiga tuturan tersebut merupakan tindak tutur ilokusi jenis dan fungsi deklarasi tiga tuturan tersebut dikatakan tindak tutur deklarasi Searle (dalam Chaer, 2010: 29) jenis dari tuturan deklarasi dikatakan karena tuturannya bermaksud untuk menunjukkan atau mengungkapkan bahwa tindakan yang dilakukan dapat mengakibatkan adanya antara bukti dengan realita. Hal ini sesuai dengan jenis yang berfungsi sebagai tindak tutur deklarasi yang terdapat pada percakapan Stigma Negatif terhadap Pasien Positif Korona antara lain, mengesankan, memutuskan, melarang, berpasrah, dan mengucilkan. Tuturan dalam penelitian tersebut tidak dapat dijelaskan secara gamblang tanpa mengetahui konteks pada percakapan tersebut sehingga tindak tutur deklarasi bersifat eksplisit. Jenis deklarasi terdapat tiga tuturan fungsi dalam percakapan stigma negatif terhadap pasien positif korona sedangkan fungsi dalam percakapan stigma negatif terhadap pasien positif korona tindak tutur ilokusi yang berfungsi sebagai memutuskan cukup banyak terdapat dua tuturan terjadi pada percakapan stigma negatif terhadap pasien positif korona tuturan.

Pada percakapan tersebut tuturan itu dimaksudkan penutur untuk memutuskan bahwa masyarakat sebaiknya mencari informasi yang lebih akurat dan sebanyakbanyaknya agar tidak menjadikan kekhawatiran yang berlebih. Tuturan deklarasi tersebut dikatakan karena cerita dalam percakapan Stigma Negatif terhadap Pasien Positif Korona juga merupakan cerminan dari kehidupan nyata yang tidak terlepas dari tindak tutur. Tuturan deklarasi berkaitan dengan menciptakan suatu hal yaitu situasi atau keadaan yang baru serta pengetahuan dan data yang dapat dibuktikan. Jadi, ujaran diinterpretasikan untuk mencari kesesuaiannya pada konteks.

\section{SIMPULAN}

Paparan data-data hasil penelitian diambil dari proses analisis data. Penjelasan ini berkaitan dengan tindak tutur ilokusi dari Searle dalam stigma negatif terhadap pasien positif korona. Adapun tindak tutur ilokusi Searle disimpulkan terdapat jenis tindak tutur ilokusi yaitu tindak tutur ilokusi representatif, direktif, ekspresif, komisif, dan deklarasi. Jenis tuturan ilokusi dapat diketahui dari kata, kalimat, dan konteks dalam tuturan tidak langsung maupun langsung serta terdapat fungsi di dalam terjenisnya sebuah tuturan tindak tutur ilokusi. Peneliti menemukan lima jenis tuturan ilokusi yang terdapat pada tuturan masyarakat terkait stigma negatif terhadap pasien positif korona.

\section{REFERENSI}

Apriastuti, N. A. A. (2017). "Bentuk, Fungsi dan Jenis Tindak Tutur dalam Komunikasi Siswa di Kelas IX Unggulan SMP PGRI 3 Denpasar”. Jurnal Ilmiah Pendidikan dan Pembelajaran, Vol. 1 (1).

Chaer, A \& Leonie A. (2010). Sosiolinguistik: Perkenalan Awal. Jakarta: Rineka Cipta.

Creswell, J. W \& Clark V. L P. (2018). Designing and Conducting Mixed Methods Research. London: United Kingdom. 
Crocker J. Major B. Steele C. (1998). Social stigma. In: Gilbert D, editor; Fiske ST, editor; Lindzey G, editor. The handbook of social psychology. 4th ed. Vol. 2. New York: McGraw- Hill, 504-553.

Eagly AH. Chaiken S. (1993). The social psychology of attitudes. Fort Worth: Harcourt Brace Jovanovich.

Erlian, W, Amril, A, \& Ena, N. (2013). Tindak Tutur Deklarasi Bahasa Minangkabau Pedagang Kakilima di Pasar Raya Padang. Jurnal Pendidikan Bahasa dan Sastra Indonesia, Vol. 1 (2), 77-163.

Gunarwan, A. (1994). "Kesantunan Negatif di Kalangan Dwibahasawan Indonesia-Jawa di Jakarta: Kajian Sosiopragmatik". Analisa Klausa, Pragmatik, Wacana,Pengkomputeran Bahasa. Jakarta: Lembaga Bahasa Unika Atma Jaya.

Indrayanti, N, Haryadi, dan Imam Baehaqie. (2019). Tindak Tutur Ilokusi Dalam Wacana Naskah Drama Deleilah Tak Ingin Pulang Dari Pesta Karya Puthut E.A. Jurnal Sastra Indonesia, Vol. 8 (1), 62-67.

Jussim L. Nelson TE. Manis M, et al. (1995). Prejudice, stereotypes, and labeling effects: sources of bias in person perception. J Pers Soc Psychol, 228-246

Kleinman, A dan Rachel, H, C. 2007. "Stigma: Sebuah Proses, Sosial, Budaya, dan Moral”. Jurnal Epidemiologi dan Kesehatan Masyarakat, Online, 63(6): 1-6, https://nrs.harvard.edu/urn-3:HUL.InstRepos, diunduh 18 Maret 2020 pukul $11: 24$.

Link BG. Struening EL. Rahav M, et al. (1997). On stigma and its consequences: evidence from a longitudinal study of men with dual diagnoses of mental illness and substance abuse. J Health Soc Behav, 177-190.

Nurkhaliza, et al. (2019). "Bentuk Tindak Tutur Ilokusi dalam Program Ini Talk Show NET TV". Journal of Arts and Humanities, Vol. 24 (1), 39-45.

Rahardi, K. (2005). Pragmatik: Kesantunan Imperatif Bahasa Indonesia. Jakarta: Erlangga.

Rianto, S. (2017). Tindak Tutur Negatif Pada Media Sosial: Studi Kasus Anak Usia Sekolah Dasar. Journal Online. (https://publikasiilmiah.ums.ac.id/bitstream/handle/11617/9140/40.pdf?seque

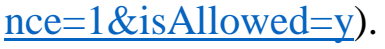

Saraswaty, D, et al. (2018). "Hubungan Dukungan Sosial Keluarga dan Pengetahuan dengan Perilaku Pengendalian Hipertensi di Wilayah". Journal Health and Sciens : Gorontalo Journal Health \& Sciens Community, Vol. 2 No.2 https://doi.org/10.35971/gojhes.v2i2.527 
Searle, J. R. (1971). The Philosophy o Language (Oxford Readings in Philosophy). London: Oxford University Press.

Senft, G. (2014). Understanding Pragmatics. London: Routledge.

Susilo, A. et al. (2019). Coronavirus Disease 2019: Tinjauan Literatur Terkini Coronavirus Disease 2019 : Review of Current Literatures. Jurnal Penyakit Dalam Indonesia, 2020; 7(1), 45- 67.

Weiner, B. (1995). Judgments of responsibility: a foundation for a theory of social conduct. New York: Guilford Pres.

Yule, G. (2006). Pragmatik. Yogyakarta: Pustaka Pelajar.

Yuliarti, R, \& Agus, N. (2015). Tindak Tutur Direktif dalam Wacana Novel Trilogi Karya Agustinus Wibowo. Jurnal Seloka, Vol. 4 (2), 78-85. 
